\title{
RIVER OF BLOOD: GEORGE MARTIN'S FEVRE DREAM AND THE ROAD TO DARK DESIGN
}

\author{
Andrew Howe \\ La Sierra University \\ Riverside, United States
}

\begin{abstract}
With his publication of Fevre Dream in 1982, George R. R. Martin tried his hand at the "sympathetic vampire" tale, one popularized just a few years previously by Anne Rice. A tale of vampires haunting the American South during the lead up to the Civil War, Fevre Dream focused upon moral ambiguity, the brutality of power, and other narrative aspects that would eventually emerge more fully developed in the author's magnum opus, the acclaimed A Song of Ice and Fire series. Often overlooked, Fevre Dream is important in that a close reading of the text indicates Martin's embrace of dark fantasy, not only in the bleak thematic material but also in the embrace of real-world historical events (the American Civil War) and institutions (slavery).
\end{abstract}

Keywords: Literature; Dark Fantasy; Horror; Vampires

George R. R. Martin did not invent or even popularize the sympathetic vampire. That trope is an old one, extending back through Anne Rice and even Bram Stoker to the mid-nineteenth century. ${ }^{1}$ With the 1982 publication of his novel Fevre Dream, however, Martin did try his hand at the vampire novel, and in so doing laid the groundwork for what would later become his dark fantasy masterpiece, $A$ Song of Ice and Fire and its inaugural novel, A Game of Thrones. Fevre Dream deals with a paddleboat captain, Abner Marsh, involved in trade along the Mississippi River in the late Antebellum period (plantation era pre-American Civil War). When he goes into business with a mysterious gentleman of wealth, the reclusive Joshua York, Marsh is slowly but inexorably drawn into a conflict between warring vampire factions. It is in this conflict that some very dark themes begin to emerge, themes that achieve maturity set against the backdrop of slavery and the lead up to the American Civil War. The rich descriptions of the river and the cities that populate its shores remind one of Mark Twain, although the gothic feel and the features of the horror genre are all Stoker. The tensions that would culminate in the Civil War-slavery, the excesses of the plantation system, and the specter of poverty for those not lucky enough to be born into that system-are largely restricted to the background of Martin's narrative. However, the late Antebellum setting lends a sense of urgency to the story. A civil war does lie at the heart of the novel, but it involves rival clans of vampires divided between those who have decided that feeding upon humans is immoral and those who cleave to their traditional attitudes and feeding habits and who refer to humans, and treat them, as "cattle." York has invented an elixir that manages the bloodthirst that plagues his species, allowing those who join him to successfully wean themselves from the need to feed upon humans. This innovation has attracted the attention of Damon Julian, a rival elder and "blood master" of incredible power with whom York must contend if he wants his cure to be embraced by even more vampires. This is the civil war that lies at the heart of Martin's text.

Throughout Fevre Dream, Martin explores some of the themes that challenge more traditional elements of high fantasy, including moral ambiguity, the brutality inherent in wielding power, the value of ruthlessness, 
and other narrative aspects that, later in his career, he would mine in much more focused and sustained ways. These elements of dark fantasy are metaphorically bound up in a series of chases and battles up and down the Mississippi River. Marsh is by no means naive, and despite the references to Twain he is portrayed as a flawed character more reminiscent of Captain Ahab. His obsession drives him as a person, captain, and ultimately as a crusader in the war to free vampires from their blood addiction. Despite the introduction of all of these dark fantasy elements, however, the novel's romantic ending indicates that Martin was not quite fully ready to embrace this convention. He would continue to explore the elements of dark fantasy during his Hollywood period (writing for Beauty and the Beast \& the revival of The Twilight Zone), he would not fully embrace this genre until A Song of Ice and Fire. The seeds for this popular series, however, were sown during his 1982 foray into the vampire narrative. As a direct predecessor to his more celebrated work, and as an early member of the "moral vampire" group of vampire narratives that continues to predominate today, Fevre Dream deserves a lot more attention than it currently receives.

The narrative begins in 1857 with a paddlewheel boat captain, Abner Marsh, who has just lost the majority of his fleet during a freak winter storm. In order to pay the bills, he agrees to partner with the mysterious Joshua York, a businessman who builds Abner his dream ship-the Fevre Dream-but has very specific dictates as to how that ship will operate on the Mississippi River. As Marsh and his crew take York and his equally eccentric friends further and further south, the truth is eventually revealed: Joshua York and his friends are reformed vampires using the Fevre Dream as a roving headquarters to search out and recruit, or destroy, fellow vampires. The crux of the issue is a concoction that York has created that will allow vampires to survive without having to feed upon humans. Over the next eight months, Marsh and York become close as the two get closer and closer to, and eventually come into conflict with, a much more powerful vampire, Damon Julian. Julian is able to defeat York and bend him to his will, and Marsh barely escapes with his life.
The story then jumps to 1870, when Marsh and York unite in order to mount one final attack upon Damon Julian. With their combined strength, York is able to defeat Julian and exert his will over the entire group of vampires, who will from now on drink his elixir rather than feed upon mankind.

The above plot summary may not sound as if it would be enough to fill a 450-page book, but in and around the major plot developments are a lot of descriptions of the river, musings about the nature of violence and evil, descriptions of those either overwhelmed by or successfully resisting desire, references to slavery, the plantation, and the Civil War, and a lot of other related content. Upon publication, reviews of Fevre Dream were scant but generally positive. Martha Jones noted that it was "characterized by a fine hand for description, a vivid portrayal of the river trade and a creative interpretation of vampire legends, the tenor of which approached the gruesome" (1770). Only six years following the publication of Anne Rice's Interview with the Vampire, even reviewers who did not find certain aspects of Martin's narrative compelling-such as Barbara Selvitella-still noted it for its fresh take on the trope: "Although the sense of menace is seldom unnerving and the suspension of disbelief is tested, the new dimensions of the traditional vampire portrayal should intrigue the devoted horror buff and sustain interest" (Selvitella 95-96). As a form of sub-generic classification, dark fantasy had yet to be identified in 1982. As such, it is high time that Martin's early work (his third novel) be re-evaluated, as a reading of the various themes indicate that it was an important early tale in our modern fascination with dark fantasy.

The majority of the novel is set in the Antebellum south, allowing Martin to explore plantation society and slave culture. Indeed, the book's denouement occurs at Cypress Landing, an indigo plantation in the Deep South. Throughout the story, notions of hierarchy and structure are explored. On his plantation, Damon Julian controls who feeds and in what order, rewarding and punishing according to his whims (26). Julian represents the upper class, described serially throughout the novel as refined, European, worldly. Even his voice is described in these terms: "liquid, soft 
and deep and sensuous, rich as a fine cognac" (23). The difference between Julian and his vampire cohort, with their silks and dinner jackets and refinement, and their servant Sour Billy Tipton, who chews and spits tobacco throughout the text, is palpable. The same is true in Marsh's description of Natchez, an important stopover for river traffic between Vicksburg and Baton Rouge. First, Marsh describes the aristocratic families who live atop the hills in the city: "aloof and arrogant, drinking their mint juleps and their sherry cobblers, icing their damned wine, amusing themselves by racing their highbred horses and hunting bears, dueling with revolvers and bowie knives over the slightest trifling affront. ... They were a fine lot, and every goddamned one of them seemed to be a colonel" (113). Next, Marsh describes the poorer sections of town, those who live "under-the-hill" in the shadow of the hilltop mansions: "The streets were mud and dust. Brothels clustered round the streamer landing and lined Silver Street, or what was left of it. Much of the street had caved into the river twenty years ago, and the walks that remained were half-sunken and lined with tawdry women and dangerous, cold-eyed foppish young men" (113-114). About the only thing these two sections of Natchez have in common is their violence. In one case, the violence revolves around perceptions of honor, in the other it is more about naked self-gain.

Naturally, as a tale unfolding in the Antebellum south, slavery plays a role in Fevre Dream, and it is in Martin's descriptions of slavery and the primary characters interactions therein that this fantastical tale achieves its darkest dimensions. Although contemporary readers experiencing Martin's depictions of slavery are certainly cognizant of the institution's decline and death at the hands of Abraham Lincoln and the Emancipation Proclamation, the same cannot be said for black characters in the narrative. This book is dark, very dark in places, and here some of Martin's proclivities for violent and unpredictable developments, for which he is renowned in his $A$ Song of Ice and Fire books, are well on display. Perhaps the most shocking of these is a development that takes place during the first confrontation between York and Julian. In order to demonstrate his point that good and evil are societal constructs, and that the real game is about strength and weakness, Julian has Tipton purchase an infant at the slave market and bring him so that he can feed upon. There, in front of a stunned York and Marsh, Julian demonstrates the strength of his resolve: "Swiftly and very delicately, he leaned over the table and brought down Sour Billy's knife and cut the infant's small right hand clean off with a single smooth stroke" (249). To York and his moral vampire compatriots, Julian's action stands as a symbol of the way in which he has allowed the thirst to dominate his being, to the point that he feels no tension at all in performing acts of sadism upon an infant in order to prove a point. To Marsh, as well as most of the human readers who likely share his pointof-view, Julian's action is more about derangement and the manner in which power, untroubled by any checks or balances, relates in a vacuum of conscience. Julian wins the day, defeating York in their stare down (the way in which vampires vie for dominance and the title "blood master") and driving Marsh off the ship. When Marsh is able to locate and confront Julian a second time several months later, the latter's explanation about why he cut off the infant's hand further underscores his twisted soul. After noting that Marsh feels no tension in eating meat, as cows are lower life forms, the evil blood master suggests that he did the infant a favor by killing it: “'A slave,' Julian said lightly. 'Property, by the laws of your own nation. Inferior, according to your own people. I spared it a life of bondage, Captain"' (344). Julian is sadistic and deranged, but he does have a twisted sort of logic in noting that slavery is, in itself, a symbolic form of consumption, one in which the oppressed is consigned to a lifetime filled with bondage and suffering instead of a flash of white teeth and brief moment of panic.

Other aspects of slavery appear throughout the text, each one underscoring the notion that whereas the specific case of evil and hierarchy focused upon involves amoral vampires led by Damon Julian, human society has much to answer for when it comes to similar transgressions. Although the "Fevre" in the title specifically refers to Yellow Fever, one might say that greed is the fever and that the symptoms are slavery and a loss of moral compass. In one scene, two slave 
hunters describe in detached, clinical fashion why they chopped three fingers off of a runaway slave's right hand in order to get her to talk: "We started with the right because we noticed she was left-handed, the man said, 'Didn't want to cripple her up too bad, you understand"' (69). Slave auctions are described in passing on several occasions as characters pass by the auction blocks, and one freed black man, the cook hired by Marsh to run the kitchen on the Fevre Dream, is later re-enslaved illegally, chained up despite his freedom papers (353). Julian and his cohort typically dine on slaves they either buy or capture, although it is interesting to note that this has more to do with safety than the vampire's buying in to human hierarchies. As Tipton, who serves as procurer, notes: "Doing in niggers is one thing, but using white folk for the thirst, that's dangerous" (80). The logic espoused by Tipton and Julian is that, as the plantation society of the Antebellum South places less value upon people of color, they will be missed less if they vanish, or their disappearance will be chalked up to an attempt to flee to the North. That is what dictates the feeding habits of the vampires. The pattern of physical consumption by Julian and his cohort thus mirrors the pattern of symbolic consumption of slaves in the South, save for one important aspect. As Martin sets up his story, there is no possibility for miscegenation. The mixing of the races, as this word entails, was a core feature of slave culture in the Antebellum South, particularly between white male members of the plantation class and black female slaves, most of whom had no choice in the matter. Despite its proscribed nature, this type of liaison was commonplace, in fact so much so that there were not only terms but also degrees of hierarchy accorded to the various products of such unions: halfcastes, quadroons, octoroons, etc. Miscegenation was critical in the Antebellum South for several reasons, one of which is that it allowed for a certain amount of "passing." Some individuals with black ancestry, but light skin, could pretend they were white in order to receive social, political, or economic opportunities due to their perceived, rather than actual, ancestry. Another important dimension of miscegenation is that it demonstrated the falsity of the argument that the two races were biologically dissimilar. Martin allows no such narrative trope in his novel. Not only are vampires and humans established to be two separate species, with no inter-breeding possible, there is no conversion process, no path by which humans can become vampires. A more recent vampire reinterpretation, The Southern Vampire Mysteries or their television adaptation, True Blood, is also set in the Deep South, albeit in the present era. This series revolves around relationships that involve miscegenation (Sookie Stackhouse as a product of both human and fae) and turning (Bill Compton as a human turned into a vampire by Lorena). The relationships between vampires and humans in Fevre Dream, however, involve only the traditional predator/ prey model and York's new views of cooperation.

Besides using elements of slavery and the plantation system in order to explore the darker aspects of his vampire novel, Martin uses conflict as another means by which to explore some of the more sinister aspects of the human psyche. In a novel that spans over 450 pages and the years 1857 to 1870 , only a few pages are dedicated to the years that include the American Civil War (1861-65), and of those only a single paragraph directly addresses the war itself (396). However, minor eruptions of more personal conflicts appear throughout the text and are set against the macroscopic, impersonal background of a nation beginning to fall apart. Humans battle humans, vampires battle vampires, and conflict appears even between inanimate objects (the race between the Fevre Dream and the Southerner, two large riverboats). Even the river itself, usually a symbol of fluidity and mobility, fits into this tendency, with the southern half of the Mississippi River described in terms (serpentine, dangerous, unpredictable) at odds with the northern half (straight, easy, navigable). (100). Although the narrative revolves around a revolution in the vampire ranks led by York, one designed to halt the age-old practice of feeding on humans and guide vampires back to greatness $(209,230)$, it is human conflict that appears, relentlessly, throughout the text, and upon which both York and Marsh spend a great deal of time reflecting. York came of age during the French Revolution and, because he and his father were perceived to be aristocratic and were known to have odd, nocturnal habits, they were targeted: "the fires of 
the revolution changed my life irrevocably. When the terror came, we were taken" (187). Before he is taken off to the guillotine, York's father makes a link between vampire and human in their allegiance to violence: “They cannot help themselves. The red thirst is on this nation, and only blood will sate it. It is the bane of us all'" (188). It is interesting to note that, throughout the text, York remembers when things occurred by their proximity to wars or other violent moments of human conflict: 1789, Napoleonic Wars, etc. Toward the end of the narrative, while musing about the Civil War, Marsh thinks about the statement York's father made about a society having given itself over to a red thirst, one that seems quite apropos to the conflict that's just taken place. Even the very manner of nation building, with ports open to immigrants from numerous different countries, adds to the conflict. At one point, Marsh notes the tension between the various groups who have taken deck passage on his steamer: "Irish and Swedes and big Dutchmen all yelling at each other in foreign languages" (39). Even when not veering toward a titanic struggle predicated upon slavery, the very makeup of the country will naturally result in misunderstanding and friction.

Not all human conflict need be so overarching as the American Civil War or French Revolution, however. The novel contains numerous episodes that range from small moments where two people strive for dominance to battles between groups that, despite their bloody nature, do not involve the entirety of society. When he meets new people, Marsh uses his size and strength to try and intimidate them while shaking hands (14), and Julian notes that his need to race, and beat, other paddlewheel boats is just an extension of this need for mastery (348). At one point, Marsh considers Southern violence, but his stream-of-consciousness moves to how the North was just as violent and typified by some of the worst aspects of Manifest Destiny and violence against indigenous populations:

Marsh had seen blood before, plenty of it; fistfights and canings, duels and shootings. The river ran down into slave country, and blood flowed easily there for those whose skin was black. The free states weren't much better. Marsh had been in bleeding Kansas for a time, had seen men burned and shot. He had served in the Illinois militia when he was younger, and had fought in the Black Hawk War. He still dreamt at times of the Battle of Bad Axe, when they'd cut down Black Hawk's people, women and children too, as they tried to cross the Mississippi to the safety of the western shore. (110)

The nineteenth century was typified not only by increased violence against African slaves following Nat Turner's rebellion and leading up to the Civil War, but also against indigenous tribes who stood in the way of "progress," usually due to the mining and/or agricultural resources present in the land upon which they had traditionally lived. York makes one of the core statements of the book: "When it comes to bloodshed, Abner, my people have very little to teach your own" (408). Perhaps the darkest element of human/human conflict in Fevre Dream involves Sour Billy Tipton. This character has violent confrontations with numerous characters in the book, at one point throwing a man into the boiler of a ship in order to intimidate the rest of the crew into working harder (326). However, it is in his desire to be a vampire that Tipton morphs from a typical, albeit particularly brutish, vampire familiar (a vampire's term for "helper") into a tragic figure driven mad by his ambition and desire. Tipton does not realize that humans cannot be made into vampires; however, in order to keep him in line, Julian has promised him just that. In 1857, Julian tells Tipton that he must begin drinking human blood and eating human flesh, as the process will take years (329). When we next see Tipton, 13 years later, he is sickly and half mad, having lived as a cannibal since his master sadistically started him on this false regimen (420). Julian toys with one of the few characters to give him unquestioning loyalty, in so doing turning the violent, murderous thug into something of a pathetic, albeit still dangerous, figure, in one of the darker elements of the text.

As a fantasy novel with decidedly dark moments and elements, Fevre Dream differentiates itself from traditional tales of modern horror in its more nuanced view of morality. Certainly, York's background in living among humans from an early age is established as critical in forming his adult opinions. Even Julian notes this 
aspect of York's worldview: "Raised among the cattle, now you think as they do"' (245). For Joshua, this is not a bad thing, as empathy is the path to understanding and, eventually, enlightenment. Martin does not make York's journey that easy, however, as that would be unrealistic. Fevre Dream is not Twilight; total and complete abstinence is not realistic, nor is it univocal to a single issue (in Twilight, teenage sexual abstinence). As York tells Marsh, his road to sobriety is filled with relapses and moments of self-doubt. When the thirst first hits him at the age of 20, and he first feeds, York is simultaneously horrified and gratified: "I felt stronger and healthier than ever in my life. Yet I was sick and horrified as well. I had grown up among your people, you see, and I thought as you did. I was no animal, no monster. There and then, I resolved to change the way I lived" (191). Under the ministrations of a lesser writer, this might have been the turning point for York, and he might not have fed again. However, this is not the case, and York continues to feed, even though he feels terrible guilt following each episode. After killing a maidservant with whom he had become quite close, York vows to find a way to reduce the red thirst and thus free himself and his people (194-196). Again, Martin proves himself a mature writer: York's vow is not as much about never feeding again, but instead about working gradually toward a process that he can put into place so that someday he will be able to resist the urge to feed. After many feedings and ideas that lead nowhere, he is able to create an elixir that removes his thirst (199-201), much as is the case with the synthetic blood drink in The Southern Vampire Mysteries. After that moment, he indeed never feeds again, and begins to track down fellow members of his own people in order that they can make the same choice he did. In so doing, York and his cohort become "good vampires," a trope that would become increasingly popular during the 1990s and 2000s with books such as The Southern Vampire Mysteries and the Twilight series, and the films and television shows based upon them. As Margaret L. Carter notes, one way to un-demonize the vampire is to bring scientific knowledge to bear: "Once the vampire's existence has a scientific rationale, the 'monster' cannot be unreflectively demonized" (166). Superstition is thus replaced by knowledge and emotion by logic, although in the end of the day the narrative of vampires defeating their addictions serves more to demystify human problems.

Ultimately, Fevre Dream is a tale about selfdiscipline as much as anything else. It is about the struggle between the id and the super-ego, about freeing the shackles one imposes upon themselves due to their lusts. Symbolically, the tale is about abstinence, not as regards adolescent sexuality as is the case in Twilight, but instead about power structures and the excesses they engender. The fact that the thirst does not arrive until the age of 20 may seem like a reference to adult sexuality, and York does indeed describe his first feeding in such terms. However, having the thirst arrive late has more to do with the fact that power is not granted in such highly structured societies until adulthood, which in and of itself provides a ray of sunshine in that such power hierarchies are perhaps learned rather than innate, an issue of nurture rather than nature. Slavery, the plantation system, and the Civil War are fairly weighty backdrops for such a study; however, it must be recognized that slavery was outlawed, the plantation system fell apart, and the Civil War ended. Damon Julian and the thirst were powerful opponents, but York was able to overcome them, due in part to his inner willpower but also to his reliance upon a friend and colleague: Abner Marsh.

Martin goes out of his way, incidentally, to note that despite the fact York perseveres, success does not come easily. Nor will it continue to do so following his victory. From the moment he meets York, Marsh notes that despite his calm exterior there are battles going on just under the surface. While looking into York's eyes, he notes the following: "There was a cool intelligence peering out of those mists. But there was a beast as well, dark and frightening, chained and angry, raging at the fog. Laughter and loneliness and cruel passion; York had all of that in his eyes" (3). It all comes down to choice. York knows he can kill and consume humans, and has done so on many occasions; he just chooses to treat them as equals. Damon Julian, however, does not. For Julian, life is merely an equation involving the survival of the fittest. Before they battle 
for control of the vampire flock (the first of four such contests), he shares his core vision with York: "YYou must understand, dear Joshua, that there is no good or evil, only strength and weakness, masters and slaves"' (246). Julian defeats York, who is forced to live with and call Julian blood master for the next thirteen years. During this time, York comes to realize that Julian is "ruined" and "empty" (366), and that he hasn't felt the thirst for hundreds of years, feeding because he chooses to feed (367). He is, as Mary Pharr notes, a symbol of "endless predation" (94), feeding because he enjoys the power rather than for an actual thirst for the blood. Julian confirms as much to Tipton, explaining to his thrall why he chooses certain victims over others: "I am power. And the essence of what I am, of pleasure and power, lies in possibility. My own possibilities are vast, and have no limit, as our years have no limit. But I am the limit to these cattle, I am the end of all their hopes, of all their possibilities ... how much finer to drink of the young, the rich, the beautiful, those whose lives stretch out ahead of them, whose days and nights glitter and shine with promise!" (123). Much like York, Julian too has made his choice, but it is one that does not require any sacrifice, and sacrifice is a quality of heroism that typifies the protagonist in a dark fantasy tale.

Fevre Dream is clearly fantasy, and for many of the reasons noted above, ones that involve not only setting (plantation society), plot (violence), and characters (morality plays), the tale is extremely dark. However, can the tale be safely classified as dark fantasy? What is it about Martin's text that differentiates it from a book in the horror genre? Dark fantasy is a notoriously slippery sub-genre/genre. As Roz Kaveney notes:

The taxonomy of genres is always a work in progress. It is a way of describing empirical data, facts that may change across time. Dark fantasy, and the subgenres which can usefully be included within it-template dark fantasy and paranormal romance-are in some measure developments of the last two decades; they are publishing categories, but also ways of thinking about texts which already existed, or which were not automatically allocated to dark fantasy on their first appearance. (214)
Although in limiting dark fantasy to two subcategories, Kaveney excludes many works of fantasy that clearly blend in elements of horror while still maintaining their fantasy core, several of her points warrant reinforcement: firstly, that literary taxonomies exist in a state of flux and are relatable to time and place; secondly, that despite this notion of cultural and temporal proximity, it is possible to go back and identify certain works, like Fevre Dream, that belong to a category that was not yet fully articulated when the work was published; and finally, that dark fantasy has largely been a publishing rather than an academic category. Most dark fantasy collections have involved short stories rather than critical essays, focusing upon example rather than definition. Christopher Golden has a more expansive vision of dark fantasy, noting it as an "umbrella" term under which horror, suspense, noir, paranormal romance, dark comedy, and other aspects of fantasy can fall (2). Golden's list is, once again, more about examples than definitions. It seems as if there must be another litmus for determining dark fantasy, one beholden to ground-up story elements, character tropes, or plot settings rather than top-down determinations of sub-genre. Certainly, dark elements of horror are found throughout the plot, setting, and characters of Fevre Dream. However, there are other elements as well that situate this tale as one of dark fantasy. The related elements of transgression, choice, and sacrifice introduce a complex system of advanced morality that exists on a much higher plane than anything that would exist in a simple tale of horror. Joshua York and Abner Marsh coming together and helping one another as equals lends a certain amount of gravitas to this tale. Each one of them makes a choice, York to vacate his position of power over humans, Marsh in risking his life in a civil war between two factions of a species he months before had not known to exist. Change does not come without a price, however. Marsh's business is lost and his aspirations destroyed; he is injured during the final conflict with Julian, and dies a few years later. Aside from losing his friend, York has made himself and his kind vulnerable by bringing attention to their existence. For him, the sacrifice is worth forging an alliance with clear-thinking men. Really, the focus in 
Fevre Dream is more in the musings on morality and sacrifice than in the action and gore. In this, the tale is more fantasy than horror. Whereas the latter is more about the emotional and the experiential, dark fantasy tales such as this are as much cerebral as emotional and cultivate the existential along with the experiential. ${ }^{2}$

It is not clear when it became fashionable to be dark, but with Fevre Dream George R. R. Martin certainly exists near the beginning of the modern trend, especially as manifest through the dark fantasy trope of the sympathetic vampire. This modern eruption of the gothic has occurred, perhaps not coincidentally, during a time of greater empowerment for women as well as changing views regarding modes of sexuality that, previously, had largely been viewed as aberrant. Much as in Joseph Conrad's Heart of Darkness, the river serves as a metaphor for desire and madness but also a means by which those who wish to can embrace a certain amount of fluidity not accorded others. And much as in Harriet Beecher Stowe's Uncle Tom's Cabin, Martin also employs the trope of increased danger the further south one progresses. It is hard to identify exactly who the hero is in Fevre Dream. As in high fantasy, there is a heroic figure, Abner Marsh, who is reluctantly pulled into the narrative. Furthermore, the fact that most of the narrative is told through his perspective suggests him as the logical choice. However, in the narrative focus upon choice, morality, and transformation, Joshua York is the better option. As York himself notes-perhaps arrogantly, but correctly-he is the agent of change: "I had begun a new epoch for my people, and yours as well. Darkness without fear, an end to hunter and prey, to hiding and despair. No more nights of blood and degradation" (202). Martin's complexity when it comes to crafting his protagonists anticipates his later, more famous work, A Game of Thrones, a novel marked not only by the death of a character-Eddard Stark-who many had perceived to be the central protagonist, but by a developing series of books where 3-4 characters can legitimately be viewed as the central protagonist. The elements of dark fantasy established in Fevre Dreamviolence examined unflinchingly, complex notions of morality, personal choice and the consequences they engender- have also found expression in A Song of Ice and Fire, arguably in richer and more complex ways. ${ }^{3}$ Despite its fantastical elements, however, Fevre Dream exists in the real world, with the Mississippi River and the Civil War adding a sense of seriousness to the issues at play that references to the Trident and the War of the Five Kings cannot. The slavery in this novel existed as described; the evil that men do is not so easily swept under the rug in this tale. Joshua York notes this aspect of humanity when first revealing himself to Marsh as a vampire. After noting that the most violent figures in history-Caligula, Vlad the Impaler, and Elizabeth Bathory-despite their reputations as potential vampires, were actually human (210-211), he points out that humans have no excuse such as the red thirst to justify murder (218). The message is simple: humanity does not need a magic elixir in order to do the right thing. Individuals and groups may be tempted by self-interest, and history is full of examples like Antebellum slavery where bad decisions were made. However, humanity is gifted with the power of choice, which does give some hope for the future.

\section{Notes}

1. The earliest origins of the sympathetic vampire can be traced back to the Varney the Vampire serial in 1845. Sondra Ford Swift suggests that the modern trope of the reinvented, more highly complex vampire extends back to Barnabas Collins in the late 1960s television show Dark Shadows (155). Others are Mick St. John in Moonlight, Louis in Interview with the Vampire, Angel \& Spike in Buffy the Vampire Slayer, and Edward Cullen in Twilight, to name a few key examples.

2. One dimension that deepens the impact of the darker fantastical elements of Fevre Dream is that the book was adapted into a graphic novel in 2011. It is one thing to read about Tipton's cannibalism or of Julian's wholesale slaughter of the ship's passengers, but it is another thing entirely to see it illustrated visually on the page. Reading the graphic novel in concert with Martin's original text adds weight to some of the already weighty story and character elements, further arguing for the text as a key one within the growing field of dark fantasy.

3. It should be noted, however, that with A Song of Ice and Fire George R. R. Martin has had five books (with two additional ones planned), thousands of pages, and nearly 20 years with which to develop all of these themes. 


\section{References}

Ball, Alan, creator. True Blood. HBO Home Video, 2014.

Carter, Margaret L. "Vampire-Human Symbiosis in Fevre Dream and the Empire of Fear." The Blood is the Life: Vampires in Literature. Ed. Leonard G. Heldreth and Mary Pharr. Bowling Green: Bowling Green University Press, 1999. 165-76.

Golden, Christopher. "An Introduction." Dark Duets: AllNew Tales of Horror and Dark Fantasy. Ed. Christopher Golden. New York: HarperCollins, 2014.

Harris, Charlaine. The Southern Vampire Mysteries. London: Orion Publishing, 2012.

Jones, Martha. “'Fever Dream." Library Journal 107.16 (Sep. 15, 1982): 1770.

Kaveney, Roz. "Dark fantasy and paranormal romance." The Cambridge Companion to Fantasy Literature. Edited by Edward James and Farah Mendlesohn. Cambridge: Cambridge University Press, 2012. 214223.

Koslow, Ron, creator. Beauty and the Beast. Paramount, 2014.

Martin, George R. R., writer. Fevre Dream. Adapted by Daniel Abraham, Art by Rafa Lopez. Rantoul: Avatar, 2011.

Martin, George R. R. Fevre Dream. New York: Bantam Books, 1982.

Martin, George R. R. A Game of Thrones. New York: Bantam Books, 1996.

Martin, George R. R. A Song of Ice and Fire. New York: Bantam Books, 2011.

Meyer, Stephanie. Twilight. New York: Little, Brown and Company, 2005.

Pharr, Mary. "Vampiric Appetite in I Am Legend, Salem's Lot, and The Hunger." The Blood is the Life: Vampires in Literature. Ed. Leonard G. Heldreth and Mary Pharr. Bowling Green: Bowling Green University Press, 1999. 93-103.

Rice, Anne. Interview with the Vampire. New York: Knopf, 1976.

Selvitella, Barbara. “"Fevre Dream." School Library Journal 29.6 (Feb. 1983): 95-96.

Serling, Ron, creator. The Twilight Zone. Image Entertainment, 2004.

Swift, Sondra Ford. "Toward the Vampire as Savior: Chelsea Quinn Yarbro's Saint-Germain Series Compared with Edward Bulwer-Lytton's Zanoni." The Blood is the Life: Vampires in Literature. Ed. Leonard
G. Heldreth and Mary Pharr. Bowling Green: Bowling Green University Press, 1999. 155-64.

Recebido em: 12/07/2016

Aceito em: 20/09/2016 